\title{
The Factors Effecting Reading Literacy in the Programme for International Students' Achievement (PISA) 2009
}

\section{Yılı Uluslararası Öğrenci Başarı Programında (PISA) Okuma Becerisini Etkileyen Faktörlere Yönelik Uygulama}

\section{Tolga COŞGUNER* Cem Oktay GÜZELLER ${ }^{* *}$}

\begin{abstract}
The aim of this study was to determine the factors effecting the reading literacy of 15 year old age-group students in Turkey, within the context of the Programme for International Student's Achievment (PISA) 2009. The study involved 4996 students. To determine the factors effecting reading literacy, analysis based on sub-problems was conducted. In this analysis, firstly an exploratory factor analysis by questionnaire was conducted concerning questions relating to interest and learning strategies. Then the defined factors were analyzed based upon confirmatory factor analysis and, finally, linear regression analysis was conducted to establish the reading literacy explanation ratio of the defined factors. Based upon these results, a 7-factor stucture related to reading literacy was derived and confirmatory factor analysis of the 7-factored structure was confirmed. This defined 7-factor structure explained 59.71 percent of the total variation. As a result of multiple linear regression analysis, it was found that the determined variables identified the 14.1 portion of reading.
\end{abstract}

Keywords: PISA 2009, Reading Literacy, Exploratory and Confirmatory Factor Analysis, Multiple Linear Regression

Öz: Bu çalışma, 2009 yılı Uluslararası Öğrenci Başarı Programı (PISA) uygulaması kapsamında Türkiye'deki 15 yaş grubu öğrencilerin okuma becerisini etkileyen faktörleri saptamayı amaçlamaktadır. Çalışma 4996 öğrenci ile yürütülmüştür. Okuma becerisini etkileyen faktörleri saptamak amacıyla alt problemlere dayalı analizler yapılmıştır. Bu analizlerde ilkin, açıklayıcı faktör analizi anketteki ilgi ve öğrenme stratejilerine ilişkin sorularla yürütülmüş̧ür; ardından tanımlanan faktörler doğrulayıcı faktör analizine bağlı olarak analiz edilmiş ve son olarak doğrusal regresyon analizi belirlenen faktörlerin açıklama oranını - okuma becerisini saptamak için yapılmıştır. Sonuçlara göre, okuma becerisine ilişkin 7 faktörlü yapı elde edilmiş ve 7 faktörlü yapı, doğrulayıcı faktör analizi teyit edilmiştir. Belirlenen bu 7 faktörlü yapı toplam değişikliğin \%59.71'ni açıklamaktadır. Çoklu doğrusal regresyon analizi sonucunda, belirlenen değişkenlerin 14.1 okuma payını tespit ettiği bulunmuştur.

Anahtar sözcükkler: PISA 2009, Okuma Becerisi, Açıklayıcı ve Doğrulayıcı Faktör Analizi, Çoklu Doğrusal Regresyon Analizi

\footnotetext{
* Lecturer, Department of Educational Sciences, Faculty of Education, University of Pamukkale, Denizli. tolgacosguner@gmail.com

**Assoc. Prof., Hacettepe University, Faculty of Education, Department of Educational Sciences, Measurement and Evaluation in Education, Ankara. cguzeller@gmail.com
} 


\section{Introduction}

Today, societies are experiencing rapid change and development and therefore, countries, societies and systems course of adjustment to this change, development, and globalizing world are gaining more importance. Within this context, national and international institutions have conducted projects such as, TIMSS, PIRLS, and PISA. PISA aims to determine the necessary knowledge and skills for those students that are at the end of their obligatory education and will participate in the modern society, through focusing upon reading, science, and maths literacy. In addition to specifying the students' knowledge and skills in reading, the PISA 2009 instrument also evaluates the students' attitudes towards the reading and learning strategies they employ and their socio-cultural backgrounds (OECD 2010a). Hauser, Edley Jr, Koenig and Elliott (2005) stated reading and writing skills are the most effective skills relating to all fields of life, such as obtaining personal objectives, increasing labor performance, and participation in a democratic society. Holloway (1999) emphasized reading skills are really important for secondary and high school students for their academic success. It is stated that success in reading skills is not only a base for success in the other fields in the education system, but also a prerequisite for participation in adult life in a variety of areas (Cunningham \& Stanovich 1998; Smith, Mikulecky, Kibby \& Dreher 2000).

In the national snap report which was published in line with the PISA 2009 application, it was stated that motivation, interest in reading and effective learning strategies can effect the students' quality of life during adolescence, and then their decision on continuing education and their capacity to obtain opportunities in the workforce (MEB 2010).

When related studies are examined, it was seen that interest in reading and activities concerning literacy are related to success in obtaining reading skills. In addition, it was determined that there are meaningful relations between self and external motivation and success in obtaining reading skills. In a study of secondary school students, it was found that perceiving the reading process as an important attainment, attendance at the reading tasks in school, and reading success are interrelating concepts. A lot of studies investigating this concern show, attitude towards reading and of reading skills success, unsurprisingly are related to each other, and this relationship is both statistically meaningful and positive. Furthermore, it can be seen that a positive attitude towards reading makes a meaningful contribution to high reading success (Rowell 1972-1973; Szymezuk \& Millard 1979; Mason 1980; Roettger, Schofield 1980; Quinn \& Jadav 1987; Gottfried 1990; Dobrich \& Hager 1991; Wigfield \& Guthrie 1997; Greene, Miller, Crowson, Duke \& Akey 2004; Scarborough, Wang \& Guthrie 2004; Unrau \& Schlackman 2006).

From these results it is understood that the interest in reading, motivation, and attitude can positively effect the acquision of reading skills success and that this in turn can help in developing senior reading skills. Moreover, there might be many signs indicative of interest, motivation, attitude towards reading skills, as also the reading strategy used, and these signs may help to explain the reading skills. Chiu \& Mcbride-Chang (2006) stated that students' interest in reading may be connected to what the students have individually filled in on the forms and the number of books they have at home, and this may be the indicator of reading success, rather than in evaluating the wide demographic properties. Van Ours (2008), remarked that reading skills are positively effected by the number of books at home. The studies conducted also show the reading materials increase development in the early stages of reading (Applebee, Langer \& Mullis 1988; Morrow 1983).

The studies show that the time spent reading for fun is a sign of the students' interests in 
their reading material and frequency of reading is closely related to reading comprehension. In accord with the student self-evaluation reports, senior reading competences are effected more through obtaining pleasure in reading and in the subject read than by any other factors in determining this competency. Many studies show that continuous reading activities and the level of understanding what is read have a strong relationship and that the reading the students do on their own and enjoy can improve senior reading skills. It was stated that interest in reading is not only related to intrinsic motivation, it is also positively related to variables such as enjoyment in reading and having a positive attitude towards reading (Cipielewski \& Stanovich 1992; Smith 1996; Baker \& Wigfield 1999; Guthrie \& Coddington 2009).

In a study conducted in different levels of classes, it was found that those students who think reading is an inner value, spend their time reading and these reading activities obtained an important place in $10^{\text {th }}$ grade students' career plans (Durik, Vida \& Eccles 2006). In the education implementation research conducted in classes, Guthrie \& Coddington (2009) specified that to be more effective, reading studies and tasks should have the capacity to support self-motivation in reading and learning. Otis, Frederick, Grouzet \& Pelletier (2005) remark that students have a really high self-motivation while they are reading for their homework. When all grade level students are analyzed, it was found out that those students with higher reading skill success take responsibility and voluntarily read in class and in the school library (Worthy, Patterson, Salas, Prater \& Turner 2002). In parallel with this situation, Assor, Kaplan, \& Roth (2002) state that whenever the students feel that the tasks are meaningless, they may become uninterested in the task and any knowledge they will learn from it. Moreover, with developing technological innovations, the impact of online reading activity in and out of school on reading skills is also rising and this situation again emphasizes the importance of reading skills. Mills (2010) suggests that the students' interest in reading may be related to online reading, the time spent in this process, and the variety of online reading material, and this is a very popular situation with many adolescents.

Students may use many different learning strategies, in order to give meaning to what they read and this may mean that there may be many different structures that effect the use of a single strategy. Generally, students that deal intensively with reading passages and are unaware of which reading strategies work for reading and comprehension, show more success in PISA reading skills (MEB 2010). Topuzkanamış and Maltepe (2010) said that a reading strategy is a solution that individuals design to solve a reading problem, and that it may contribute to a process of planned and consistent knowledge acquisition. Karasakaloğlu (2010) stated the reading comprehension strategy might bring to a high level the success of an individual, and that there is a positive and meaningful relationship between analytical and pragmatical strategy use and academic success. Köksal and Ünal (2008) explained that with the texts that are read through intertextual reading, reading comprehension reaches a higher level, and, the types of texts should be determined in reading comprehension through intertextual reading.

The studies show that those students who read on a wide range of topics and that can transfer the strategy used into a specific area are more successful than the other effective learning students, and that reading activities employing learning strategies effectively and being a senior reader effect each other. Taking interest and pleasure in reading and being a senior reader and employing learning strategies effectively have a strong correlation with each other. In these studies, it is stated that the strongest motivation behind using the learning strategies is the interest in reading and the learning process that happens in this way is a really productive one (Schiefele 1991, 312; Guthrie \& Wigfield 2000; Nurmi, Aunola, Salmela-Aro \& Lindoros 2003; Schiefele 2009; OECD, 2010b). Zimmerman \& Clearly (2009) stated that in order for 
students to further their own learning, they should chose their learning objectives, use their present knowledge and skills directly for their own learning, and chose the appropriate learning strategies for their learning tasks. Schiefele (1991) remarked that resulting from many experimental studies, interest has a variety of effects on learning, and as a result, high quality learning experience and the use of learning strategies are found.

Many studies in parallel with these show there is a relationship between the use of a self regulatory learning strategy and motivation. There is also a large relationship between self regulatory strategy use and academic success, and there is a positive relationship between self regulatory learning strategy use and verbal competence. The self regulatory activities, motivation, and beliefs of the students are emphasized as being important for the evaluation and improvement of their performances. It is also stated that the time spent reading for pleasure is the largest source of learning motivation and for summarizing information, it is necessary to know which strategy is suitable, and this is only possible through higher cognitive and self regulatory activities (Zimmerman \& Pons 1986; 1990; Zimmerman \& Clearly 2009).

Zimmerman \& Pons (1990) state that there is a large diversity in learning strategies, and they term them: self regulation, organizing and conversion, objective regulation and planning, searching the information, recording and watching, environmental configuration, self elicitation, practice and memorization, specifying a research assistant (peer, teacher, or other friends), reviewing the applied test, the notes, or the text. Schiefele (1991) characterises the learning strategies as: practice, exploration, organizing, researching the information, time management, and critical thinking.

The present study aimed to find the variables that effected the reading skills of Turkish students that completed their primary education and the level at which these variables explain the reading skills in the light of the PISA data whose basic focus in its 209 application is reading skills. Since it was done for the first time in the Turkey applications through the data from the PISA 2009, which is based upon reading strategies, and since it reveals the factors effecting reading skills, the present study is important. The main question of the study was: "How does the 15 years old International Student Assessment Project (PISA) 2009 application participant, the Turkish students' interest in reading and learning strategies effect their reading skills success?". This data was analyzed under three sub-problems related to this main problem, the sub problems are listed below.

1. How does the 15 year old PISA 2009 application participant, the Turkish students' level of reading interest and the variables related to the learning strategies that they use, effect reading skills success?

2. Could the variables that were determined be effecting the reading strategies success of the 15 year old PISA 2009 application participant Turkish students be specified correctly?

3. At what level does the interest in reading and the level of reading strategy use of the 15 year old International Student Assessment Project (PISA) 2009 application participant Turkish students explain reading skills success?

\section{Method}

In this part of the study, explanations as to the research type and data analysis with the population and sampling were made. In this study conducted under the light of the Programme for International Student Assessment (PISA) 2009 application data, the relational screening model was used. 


\section{The Population and the Sampling of the Study}

The population of the present study is all the 15 year old students that go to school in Turkey. The sampling of the study was 4996 students that were randomly chosen from 170 schools in 56 different provinces from 12 statistical areas in Turkey through stratification according to school types.

\section{Data Collection}

In the present study as data collection tools, reading skills tests and mathematical cognitive tests, and student and school surveys used in PISA 2009 practice were employed. The data obtained were taken from the PISA 2009 data files in the PISA database via the internet. Considering the properties to be used in the research, from the data obtained from PISA 2009 students and the school survey, items were selected, arranged in an electronic environment and the necessary coding was performed.

\section{Data Analysis}

In order to determine the factors effecting reading skills success, analyses were carried out in accordance with the sub-problems. Firstly, exploratory factor analysis (EFA), secondly a confirmatory factor analysis (CFA) and finally multiple regression analysis, and all of the numerals of the analysis were performed using SPSS 13.0 and LISREL 8.4. software packages.

\section{Results and Interpretation}

In this part of the study, the results and interpretations obtained from the analysis in accordance with sub-problems are presented.

$I^{\text {st }}$ Sub-problem: How does the level of interest in reading and the learning strategies of fifteen-year-old Turkish students who attended the Project of International Student Assessment (PISA) 2009 effect their reading skills success?

In order to find the answers to the sub-problem given, firstly whether the factor analysis of the findings obtained as a result of the PISA 2009 were suitable for the study was examined with the KMO and the Bartlett sphericity test. As a result of the analysis performed, the KMO value was calculated as 0.963 and the Bartlett sphericity value as $\chi^{2}=171293,040$ and $\mathrm{P}=0.000(\mathrm{P}<$ $0.001)$, respectively. When these values were examined, it was seen that the KMO value was excellent (Albayrak, 2006), and the Bartlett sphericity value was significant (Şencan 2005). From these results, it can be stated that the data was appropriate for the factor analysis of the data obtained from PISA 2009 to be performed. In this context, examining the data obtained from PISA 2009, 9 factors were identified related to reading skills success and exploratory factor analysis was performed on these factors. As the factorization technique, the principal component analysis (PCA) technique was used. While deciding the number of factors arising as a result of the exploratory factor analysis, Eigen value, variance ratio explained and scree plot chart were considered (Kline 1994). Accordingly, those factors with an Eigen value over 1 were identified; examining the variance ratio explained and the scree plot chart, a seven-factor structure was found. This seven-factor structure explained $59.7 \%$ of the total variance. The results of these analyses are presented in Table 1 and Figure 1. 
Table 1. Exploratory Factor Analysis Results Regarding Reading Skills Success

\begin{tabular}{|l|c|c|c|}
\hline Factor & eigen value & Variance (\%) & $\begin{array}{c}\text { Cumulative } \\
\text { variance (\%) }\end{array}$ \\
\hline Reading for School & 13.574 & 25.611 & 25.611 \\
\hline Enjoyment of reading & 6.731 & 12.700 & 38.311 \\
\hline Diversity of on-line reading activities & 4.006 & 7.558 & 45.869 \\
\hline Understanding and remembering & 2.535 & 4.783 & 50.652 \\
\hline Control strategies & 2.041 & 3.851 & 54.503 \\
\hline Diversity of reading material & 1.602 & 3.023 & 57.527 \\
\hline Memorisation strategies & 1.158 & 2.185 & 59.711 \\
\hline
\end{tabular}

7 factors determined by the eigen value criterion can be seen in the scree plot chart and the results of the scree plot chart confirmed this seven-factor structure. Scree plot graph is as shown in Figure 1.

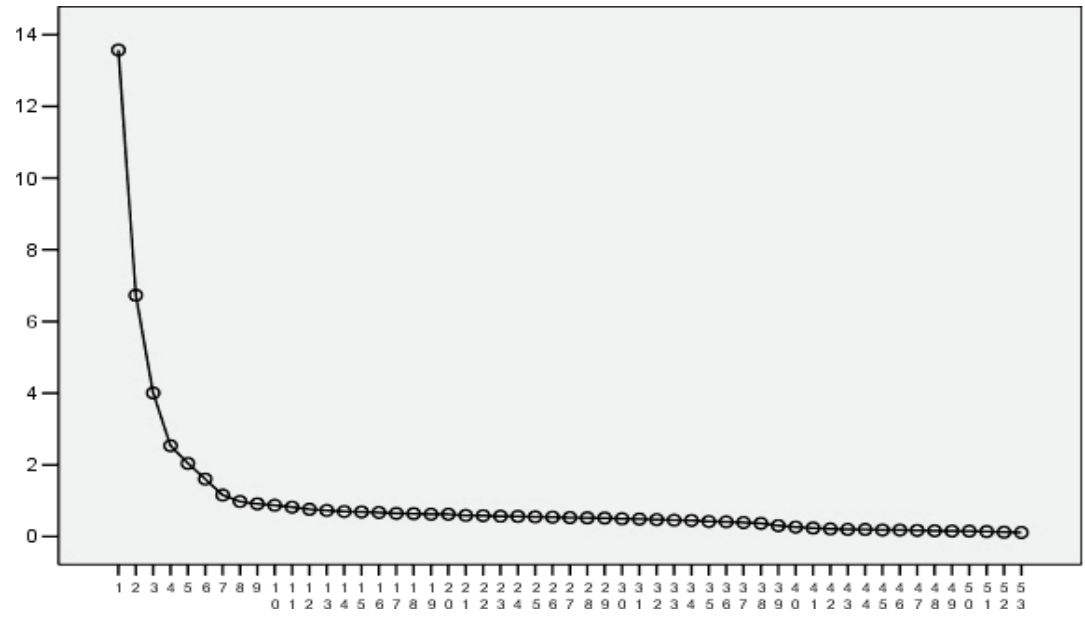

Fig. 1. Exploratory Factor Analysis Scree Plot Graph

In the exploratory factor analysis, various criteria were developed in order to find out whether variables related to the properties that were measured, or the items of a test were associated with the variable they measured, and also to determine the level of relation. The study of the related literature indicated that factor loadings ranging from 0.30 to 0.40 could be taken as the lower cut-off point while forming the factor structure (Hair, Anderson, Tahtam \& Black 1998; Büyüköztürk 2002; Şencan 2005; Çokluk, Şekercioğlu \& Büyüköztürk, 2010; Büyüköztürk 2012). In this study, following the criteria that the lower cut off point for the factor loading values was 0.32 , and the difference between the cross-loading values was at least 0.10 (Büyüköztürk 2012), the values that were obtained from the exploratory factor analysis were examined and some items were removed from the factor analysis. The values for the factor loadings are given in Table 2. 
Table 2. Factor Loading Values Obtained from the Exploratory Factor Analysis Related to Reading Skills Success

\begin{tabular}{|c|c|c|c|c|c|c|c|}
\hline & \multicolumn{7}{|l|}{ Faktör } \\
\hline & 1 & 2 & 3 & 4 & 5 & 6 & 7 \\
\hline Reading for school 10 & 0.912 & & & & & & \\
\hline Reading for school 17 & 0.905 & & & & & & \\
\hline Reading for school 11 & 0.904 & & & & & & \\
\hline Reading for school 9 & 0.901 & & & & & & \\
\hline Reading for school 16 & 0.900 & & & & & & \\
\hline Reading for school 13 & 0.895 & & & & & & \\
\hline Reading for school 15 & 0.894 & & & & & & \\
\hline Reading for school 7 & 0.894 & & & & & & \\
\hline Reading for school 12 & 0.891 & & & & & & \\
\hline Reading for school 6 & 0.878 & & & & & & \\
\hline Reading for school 14 & 0.874 & & & & & & \\
\hline Reading for school 3 & 0.873 & & & & & & \\
\hline Reading for school 8 & 0.872 & & & & & & \\
\hline Reading for school 2 & 0.868 & & & & & & \\
\hline Reading for school 1 & 0.867 & & & & & & \\
\hline Reading for school 4 & 0.867 & & & & & & \\
\hline Reading for school 5 & 0.857 & & & & & & \\
\hline Enjoyment of reading 4 & & 0.690 & & & & & \\
\hline Enjoyment of reading 11 & & 0.678 & & & & & \\
\hline Enjoyment of reading 8 & & 0.678 & & & & & \\
\hline Enjoyment of reading 6 & & 0.671 & & & & & \\
\hline Enjoyment of reading 2 & & 0.668 & & & & & \\
\hline Enjoyment of reading 7 & & 0.658 & & & & & \\
\hline Enjoyment of reading 3 & & 0.650 & & & & & \\
\hline Enjoyment of reading 5 & & 0.630 & & & & & \\
\hline Enjoyment of reading 10 & & 0.589 & & & & & \\
\hline Enjoyment of reading 9 & & 0.577 & & & & & \\
\hline Enjoyment of reading 1 & & 0.568 & & & & & \\
\hline Diversity of on-line reading activities 2 & & & 0.828 & & & & \\
\hline Diversity of on-line reading activities 3 & & & 0.790 & & & & \\
\hline Diversity of on-line reading activities 1 & & & 0.769 & & & & \\
\hline Diversity of on-line reading activities 4 & & & 0.761 & & & & \\
\hline Diversity of on-line reading activities 5 & & & 0.719 & & & & \\
\hline Diversity of on-line reading activities 6 & & & 0.693 & & & & \\
\hline Diversity of on-line reading activities 7 & & & 0.677 & & & & \\
\hline Understanding and remembering 5 & & & & 0.707 & & & \\
\hline Understanding and remembering 4 & & & & 0.705 & & & \\
\hline Understanding and remembering 3 & & & & 0.646 & & & \\
\hline Understanding and remembering 6 & & & & 0.637 & & & \\
\hline Understanding and remembering 1 & & & & 0.627 & & & \\
\hline Understanding and remembering 2 & & & & 0.572 & & & \\
\hline Control strategies 11 & & & & & 0.698 & & \\
\hline Control strategies 2 & & & & & 0.675 & & \\
\hline Control strategies 6 & & & & & 0.657 & & \\
\hline Control strategies 9 & & & & & 0.626 & & \\
\hline Diversity of reading material 1 & & & & & & 0.704 & \\
\hline Diversity of reading material 2 & & & & & & 0.700 & \\
\hline Diversity of reading material 3 & & & & & & 0.606 & \\
\hline Diversity of reading material 4 & & & & & & 0.521 & \\
\hline Memorisation strategies 3 & & & & & & & 0.715 \\
\hline Memorisation strategies 1 & & & & & & & 0.705 \\
\hline Memorisation strategies 5 & & & & & & & 0.625 \\
\hline
\end{tabular}


The percentage of total variance explained by the variables determined as a result of the exploratory factor analysis was found to be $59.71 \%$. As seen in Table 2, the first dimension of reading skills success occurring as a result of the exploratory factor analysis was formed by "reading for school". This dimension comprised 17 items and the loading values of the items varied from 0.857 and 0.912 . The second dimension, of "enjoyment of reading". This dimension consisted of 11 items and the loading values of the items varied from 0.677 to 0.828 . The third dimension, of "diversity of on-line reading activities". This dimension comprised 7 items and the loading values of the items varied from 0.677 to 0.828 . The fourth dimension, of reading skills success was, "understanding and remembering". This dimension consisted of 6 items and the loading values of the items varied from 0.572 to 0.707 . The fifth dimension was "Control strategies". This dimension comprised 4 items and the loading values of the items varied from 0.626 to 0.698 . The sixth dimension variable was "diversity of reading material". This dimension consisted of 4 items and the loading values of the items varied from 0.521 to 0.704 . Finally, the seventh dimension of the variable was "memorisation strategies". This dimension comprised 3 items and the loading values of the items varied from 0.625 to 0.715 .

$2^{\text {nd }}$ Sub-problem: In this part of the study, the findings and interpretations of the subproblem - "Were the variables whose effects were identified on the reading skills success of fifteen-year-old Turkish students who attended the Project of International Student Assessment (PISA) 2009 able to be determined correctly?" are presented.

Şimşek (2007) stated that confirmatory factor analysis was generally preferred after the exploratory factor analysis. The values determined for the confirmatory factor analysis are shown in Table 3.

Table 3. Goodness of Fit Values of the Reading Skills Success Confirmatory Factor Analysis ${ }^{*}$

\begin{tabular}{|l|c|c|c|}
\hline \multicolumn{1}{|c|}{ Fit Index } & Good Fit & Acceptable Fit & $\begin{array}{c}\text { Acquired } \\
\text { Adaptive Values }\end{array}$ \\
\hline$\chi^{2} / \mathrm{sd}$ & $0 \leq \chi^{2} / \mathrm{sd} \leq 2$ & $2<\chi^{2} / \mathrm{sd} \leq 5$ & 6.11 \\
\hline RMSEA & $0 \leq \mathrm{RMSEA} \leq 0.05$ & $0.05<\mathrm{RMSEA} \leq 0.08$ & 0.032 \\
\hline SRMR & $0 \leq \mathrm{SRMR} \leq 0.05$ & $0.05<\mathrm{SRMR} \leq 0.10$ & 0.032 \\
\hline NFI & $0.95 \leq \mathrm{NFI} \leq 1.00$ & $0.90 \leq \mathrm{NFI}<0.95$ & 0.99 \\
\hline NNFI & $0.97 \leq \mathrm{NNFI} \leq 1.00$ & $0.95 \leq \mathrm{NNFI}<0.97$ & 0.99 \\
\hline CFI & $0.97 \leq \mathrm{CFI} \leq 1.00$ & $0.95 \leq \mathrm{CFI}<0.97$ & 0.99 \\
\hline GFI & $0.95 \leq \mathrm{GFI} \leq 1.00$ & $0.90 \leq \mathrm{GFI}<0.95$ & 0.95 \\
\hline AGFI & $0.90 \leq \mathrm{AGFI} \leq 1.00$ & $0.85 \leq \mathrm{AGFI}<0.90$ & 0.94 \\
\hline
\end{tabular}

* The expressions in the figure were prepared using the sources below:

Schermelleh-Engel, Moosbrugger \& Müller, (2003). Evaluating the Fit of Structural Equation Models: Tests of Significance and Descriptive Goodness-of-Fit Measures, Methods of Psychological Research Online, 8 (2), 23-74, Şimşek (2007), Yapısal Eşitlik Modellemesine Giriş Temel Illkeler ve LISREL Uygulamalarl.

When the results of confirmatory factor analysis were examined, chi-square's rate, which is one of the statistics of calculated goodness of fit, to the degree of freedom was found as $\left[\chi^{2}=\right.$ 7351.48, $\mathrm{sd}=1203, \mathrm{P}<0.001], \chi^{2} / \mathrm{sd}=6.11$ after modifications between items had been performed. While this value wasn't among the acceptable adaptive values (Anderson \& Gerbing, 1988; Byrne, 1989; Kline, 1991), other fit index were examined in a detail way because $\chi^{2}$ was too sensitive to the sample size (Özdamar, 2004). In this way, other goodness of fit statistics 
were found as RMSEA $=0.032, \mathrm{SRMR}=0.032, \mathrm{NFI}=0.99, \mathrm{NNFI}=0.99, \mathrm{CFI}=0.99, \mathrm{GFI}=$ 0.95 , AGFI $=0.94$. In the light of this data, it can be thought that the acquired results have perfect adaptive values. These findings corroborate the factor structure in the exploratory factor analysis. In Figure 2., the values which belong to reading skills success confirmatory factor analysis model are given.

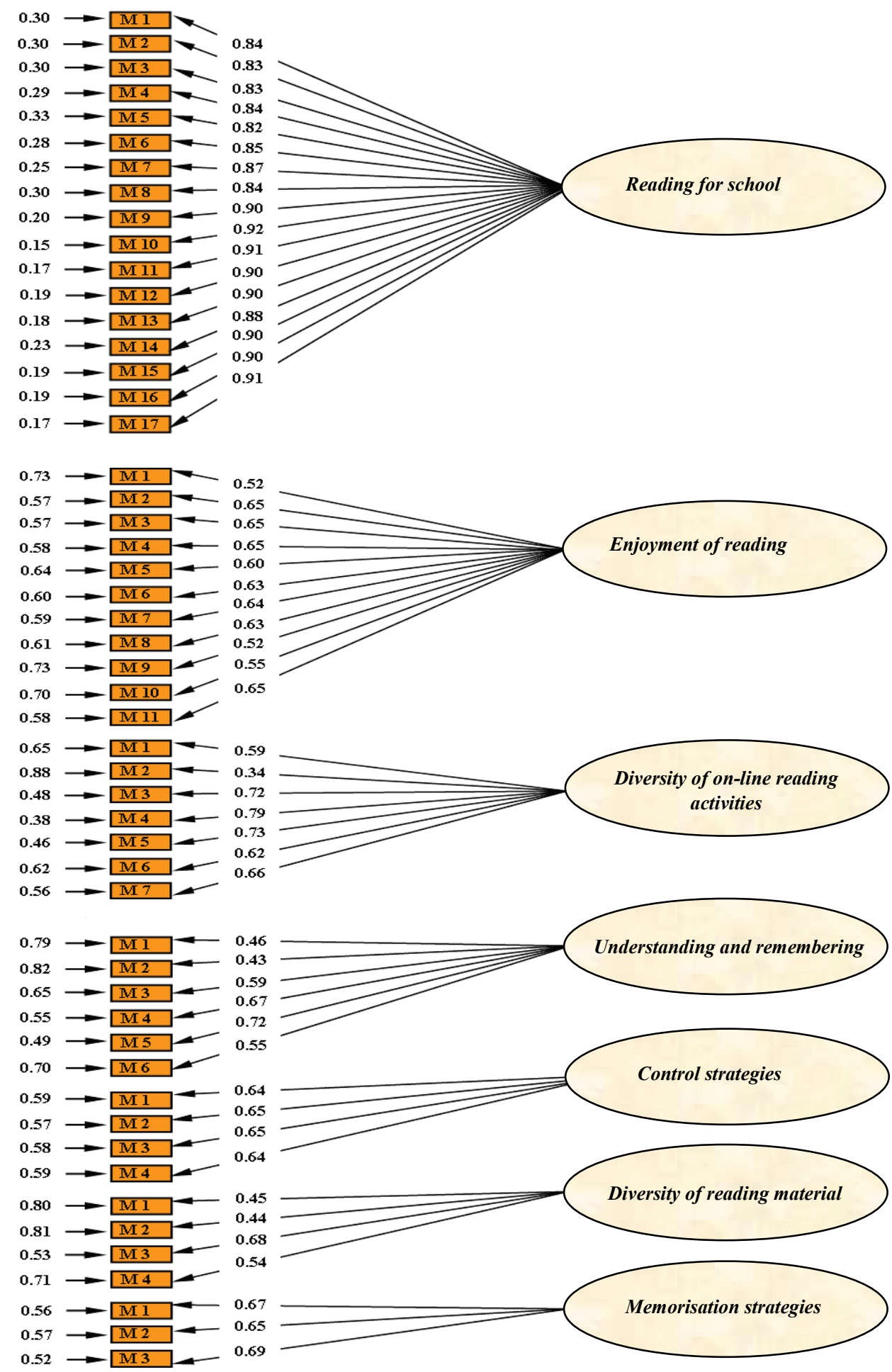

Fig. 2. Reading Skills Success Confirmatory Factor Analysis Model. 
$3^{r d}$ Sub-problem: In this part of the research, findings and interpretations which belong to the sub-problem - "At what rate does the level of interest in reading and use of learning strategies of 15-year-old Turkish students who attended Project for International Student Assessment 2009 (PISA) explain their reading skill success?" - are presented.

Multiple linear regression analysis was performed in order to determine the impacts of the seven-factor structure, which belonged to the reading skills success that was determined by exploratory factor analysis and was verified by confirmatory factor analysis, on the success of the reading skills. For the realization of multiple linear regression analysis, the data obtained has to be composed of continuous data on at least equal interval scale. For the realization of multiple linear regression analysis, another assumption is that the dependent variable requires to show a normal distribution. In the light of these explanations, the data obtained regarding the success of reading skills was the continuous data obtained on an equally spaced scale. In accord with the examinations made, the success of reading skills showed a normal distribution. According to Büyüköztürk (2012) and Tabachnick \& Fidell (2001), a problem which is defined as the multiple connectednesses between the predictor variables in a multiple regression analysis may be encountered. Binary correlations between the independent variables could be examined first, if there is a multi-link on the data layout. Also, the multiple connectivity problems between the independent variables can be tested with the variance inflation factor (VIF). The fact that VIF values equal to 1 or they are between 1 and 5 (Özdamar 2009) means that there is no multiple connections problem. From these explanations the VIF values regarding the independent variables were calculated: enjoyment of reading $=1.293$, diversity of reading material $=1.281$, diversity of on-line reading activities $=1.119$, reading for school $=1.020$, control strategies $=1.511$, memorisation strategies $=1.346$, understanding and remembering $=1.108$. In Table 4, the correlation values regarding the independent variables are given.

Table 4. The Correlation Coefficient Values Regarding the Independent Variables

\begin{tabular}{|c|c|c|c|c|c|c|c|}
\hline & $\begin{array}{l}\text { Enjoyment } \\
\text { of reading }\end{array}$ & $\begin{array}{l}\text { Diversity of } \\
\text { reading } \\
\text { material }\end{array}$ & $\begin{array}{l}\text { Diversity } \\
\text { of on-line } \\
\text { reading } \\
\text { activities }\end{array}$ & $\begin{array}{l}\text { Reading } \\
\text { for school }\end{array}$ & $\begin{array}{l}\text { Control } \\
\text { strategies }\end{array}$ & $\begin{array}{l}\text { Memorisation } \\
\text { strategies }\end{array}$ & $\begin{array}{l}\text { Understanding } \\
\text { and } \\
\text { remembering }\end{array}$ \\
\hline $\begin{array}{l}\text { Enjoyment of } \\
\text { reading }\end{array}$ & 1 & & & & & & \\
\hline $\begin{array}{l}\text { Diversity of } \\
\text { reading material }\end{array}$ & $0.350 * *$ & 1 & & & & & \\
\hline $\begin{array}{l}\text { Diversity of on- } \\
\text { line reading } \\
\text { activities }\end{array}$ & $0.086^{* *}$ & $0.290 * *$ & 1 & & & & \\
\hline $\begin{array}{l}\text { Reading for } \\
\text { school }\end{array}$ & $0.098 * *$ & $0.058^{* *}$ & $0.049 * *$ & 1 & & & \\
\hline $\begin{array}{l}\text { Control } \\
\text { strategies }\end{array}$ & $0.383^{* *}$ & $0.279 * *$ & $0.188^{* *}$ & $0.080^{* *}$ & 1 & & \\
\hline $\begin{array}{l}\text { Memorisation } \\
\text { strategies }\end{array}$ & $0.213 * *$ & $0.240 * *$ & $0.154 * *$ & $0.076^{* *}$ & $0.486^{* *}$ & 1 & \\
\hline $\begin{array}{l}\text { Understanding } \\
\text { and } \\
\text { remembering }\end{array}$ & $0.223 * *$ & $0.197 * *$ & $0.075^{* *}$ & $0.063 * *$ & $0.243 * *$ & $0.211^{* *}$ & 1 \\
\hline
\end{tabular}


When Table 4 was examined, it was seen that the highest level of correlation was between memorisation strategies and control strategies $(\mathrm{r}=0.486)$. When the correlation and VIF values between the independent variables were examined, it was found that there were no connection problems as the highest level of correlation is 0.486 and the VIF values were close to 1 ranging between 1 and 5. The results of multiple linear regression analysis performed on the success factors for reading skills can be seen in Table 5 .

Table 5. The Results of Multiple Linear Regression Analysis of The Success Factors for Reading Skills

\begin{tabular}{|c|c|c|c|c|c|c|c|}
\hline & \multicolumn{2}{|c|}{ Unstandardized } & \multirow{2}{*}{$\begin{array}{l}\text { Standardized } \\
\text { Regression }\end{array}$} & & & & \\
\hline & & & & & & & \\
\hline & & Standard & Coefficient & & & Binary & Partial \\
\hline & B & Error $_{B}$ & $(\beta)$ & $\mathrm{t}$ & $\mathrm{P}$ & $\mathrm{r}$ & $\mathrm{r}$ \\
\hline Invariant & 460.276 & 7.019 & - & 65.576 & 0.000 & - & - \\
\hline Enjoyment of reading & 17.230 & 1.797 & 0.143 & 9.588 & 0.000 & 0.135 & 0.126 \\
\hline Diversity of reading material & 11.435 & 1.349 & 0.126 & 8.479 & 0.000 & 0.119 & 0.111 \\
\hline Diversity of on-line reading activities & 8.440 & 1.177 & 0.099 & 7.168 & 0.000 & 0.101 & 0.094 \\
\hline Reading for school & 4.613 & 0.516 & 0.118 & 8.934 & 0.000 & 0.125 & 0.117 \\
\hline Control strategies & 22.288 & 1.631 & 0.220 & 13.665 & 0.000 & 0.190 & 0.179 \\
\hline Memorisation strategies & 31.597 & 1.435 & 0.335 & 22.025 & 0.000 & 0.298 & 0.289 \\
\hline Understanding and remembering & 3.283 & 1.002 & 0.045 & 3.275 & 0.001 & 0.046 & 0.043 \\
\hline $\mathrm{R}=0.378 \quad \mathrm{R}^{2}=0.141$ & & & & & & & \\
\hline $\mathrm{F}_{(7,4988)}=118.543 \quad \mathrm{p}=0.000$ & & & & & & & \\
\hline
\end{tabular}

RSAS: reading skills success score; ER: Enjoyment of reading; DRM: Diversity of reading material; DORA: Diversity of on-line reading activities; RS: Reading for school; CS: Control strategies; MS: Memorisation strategies; UR: Understanding and remembering.

When Table 5 was examined, it was concluded that as the $\mathrm{F}$ value obtained from the regression analysis was significant at a level of 0.01 , the regression model was appropriate [F $(7,4988)=118.543 ; p<0.01]$. Enjoyment of reading, diversity of reading material, diversity of on-line reading activities, reading for school, control strategies, memorisation strategies and understanding and remembering, together all revealed a moderate and significant correlation with reading skills success $(\mathrm{R}=0.378, \mathrm{R} 2=0.141, \mathrm{p}<0.01)$. Together the seven variables mentioned above explain about $14.1 \%$ of the total variance in reading skills success. The remaining $85.9 \%$ variation was determined by variables not included in this model. When the Ttest results regarding the significance of the regression coefficient were examined, it was seen that enjoyment of reading, the diversity of reading material, the diversity of on-line reading activities, reading for school, control strategies, memorisation strategies and understanding and remembering are a significant predictor of reading skills success. According to the results of multiple regression analysis, the regression equation for the prediction of reading skills success was as follows:

Reading skills success $=460.276+17.230 *(\mathrm{ER})-11.435 *(\mathrm{DRM})+8.440 *(\mathrm{DORA})-$ $4.613 *(\mathrm{RS})+22.288 *(\mathrm{CS})-31.597 *(\mathrm{MS})-3.283 *(\mathrm{UR})$

When the equation was analyzed, it was seen that enjoyment of reading, diversity of on-line reading activities and control strategies had positive effects on reading skills success score. However, it was found that diversity of reading material, reading for school, memorisation strategies and understanding and remembering have negative effects on the reading skills 
success score. According to the standardized regression coefficient $(\beta)$, the relative order of importance of the predictor variables on reading skills success was found to be as follows: Memorisation strategies, control strategies, enjoyment of reading, diversity of reading material, reading for school, diversity of on-line reading activities, and lastly, understanding and remembering.

According to the results of the regression analysis, it was found that enjoyment of reading had a positive impact on reading skills success. This finding of the study was consistent with many studies carried out on this issue (Rowell 1972-1973; Roettger, Szymezuk \& Millard 1979; Mason 1980; Schofield 1980; Quinn \& Jadav 1987; Gottfried 1990; Scarborough, Dobrich \& Hager 1991; Schiefele 1991; Cipielewski \& Stanovich 1992; Smith 1996; Wigfield \& Guthrie 1997; Baker \& Wigfiield 1999; Nurmi, Aunola, Salmela-Aro \& Lindoros 2003; Wang \& Guthrie 2004; Greene, Miller, Crowson, Duke \& Akey 2004; Grouzet \& Pelletier 2005; Durik, Vida \& Eccles 2006; Unrau \& Schlackman 2006; Schiefele 2009; Otis, Frederick, Guthrie \& Coddington 2009; Zimmerman \& Clearly 2009).

After analyzing the values relating to diversity of reading material, it was seen that it negatively effected reading skills success. The result obtained differed from the studies conducted on this issue and the related literature. Studies show that reading materials increase individuals' development in their first reading period (Morrow 1983; Applebee, Langer \& Mullis 1988). Smith (1996) stated in a study he did by examining the self-assessment reports of the students that high-level reading competencies were effected by the reading materials. Chiu \& McbrideChang (2006) suggested that the students' interest in reading might be associated with the forms they stated individually and the number of books they had at home and this state could be an indicator of reading success rather than the measurement of large scale demographic features. Van Ours (2008) stated reading skills were effected negatively by the number of books at home. The analysis of the Ministry of Education national preliminary report indicated that students studying a great variety of materials in all the countries where PISA project was carried out, except for Turkey and Kazakhstan, showed a better performance compared to students studying a smaller variety of materials. This result could be considered to have arisen from the different parameters of our country.

When the findings of the study related to diversity of on-line reading activities were examined, it was found that they positively effect reading skills success. This result is in line with Mills' work (2010). The analysis of the findings regarding the reading for school indicated that they had a negative effect on reading skills success and this result is consistent with the study of Assor et al. (2002). According to Assor et al. (2002), whenever students found the tasks performed for school meaningless, they could remain indifferent to the task and the information to be learnt. In addition, Guthrie \& Coddington (2009) stated that reading practices and tasks should support self-motivation for reading and learning to be more efficient. Otis et al. (2005) stated that most of the students had a very high self-motivation while reading for homework. In a study they carried out with secondary school students, Miller, Crowson, Duke \& Akey (2004) suggested that with the consideration of the reading process as a significant value, reading tasks performed at school and reading success were interconnected concepts. It was stated that students with high reading skills success, read books in the class or in the school library willingly through accepting responsibility (Worthy, Patterson, Salas, Prater \& Turner 2002). In a study conducted at a different grade level, it was stated that students considering reading as an intrinsic value, made use of their time reading books (Durik, Vida \& Eccles 2006).

The findings related to control strategies effected reading skills success positively and this 
result is in line with many other studies (Zimmerman \& Pons 1986; 1990; Guthrie \& Wigfield 2000; Nurmi, Aunola, Salmela-Aro \& Lindoros 2003; Schiefele 2009; Zimmerman \& Clearly 2009). Karasakaloğlu (2010), reading comprehension strategy could increase an individual's success to a higher level and the use of analytical and pragmatic strategies had a positive and meaningful connection with high level academic success. According to Köksal and Ünal (2008), in order to comprehend and make sense of a text, it was necessary to exploit reading strategies. When the findings regarding understanding and remembering were examined, it was observed that it had a difference from these explanations. The impact of understanding and remembering was weak and it negatively effected reading skills success.

The analysis of the findings related to memorisation strategies indicated it had a negative effect on reading skills success. Schiefele (1991) expressed in a study he carried out that readers who were interested in the text might have aims other than memorizing the text. According to Topuzkanamış and Maltepe (2010), reading strategies were a solution that individuals designed to solve the reading problems they encountered and also that they might contribute to the process of obtaining planned and permanent information. It is remarkable that memorisation strategies are relatively, the largest among the seven factors effecting reading skills success and this effect was determined to be in a negative direction. Accordingly, memorisation strategies can be considered to have a negative effect on performing higher-level mental activities and the process of obtaining permanent information, within the scope of reading skills success.

\section{Conclusion and Recommendations}

From the findings obtained from the PISA 2009 Turkey implementation, and according to the order of the defined sub-problems, the aim of this research was to determine the relationship between the variables found in the dimension of having an interest in reading and the dimension of learning strategy and of reading skills success. For this purpose, first of all exploratory factor analysis was carried out and as a result of this, the variable with the most important and highest values was detected to be "reading for school" among the variables whose variance rate explained with factor loading was determined. "enjoyment of reading", "diversity of on-line reading activities", "understanding and remembering", "control strategies", "diversity of reading material" and "memorisation strategies" followed this variable respectively. The seven-factor theoretical structure resulting from the exploratory factor analysis explained $59.7 \%$ of the total variance. With these results, confirmatory factor analysis was performed to investigate whether the observed and latent variables were significant. As a result of the confirmatory factor analysis, this seven-factor theoretical structure which comprised the components of the interest and learning strategies associated with reading skills success and which was determined by exploratory factor analysis was confirmed.

As a result of multiple regression analysis performed to determine the seven-factor (variables) theoretical structure's level and forms of effects upon reading skills success, it was seen that this seven-factor structure mentioned moderately effected reading skills success. This structure obtained explained $14.1 \%$ of reading skills success. From the t-test results for the significance of regression coefficients, it was determined that all the existing seven structures were significant predictor variables on reading skills success.

When the results regarding memorisation strategies were examined, it was observed that it was relatively the largest factor amongst those factors effecting reading skills success and this effect was in the negative direction. For this reason, abandoning "memorisation strategies" and adopting modern educational approaches and practices towards improving high-level mental skills should be taken. 
When the results for the "control strategies" were examined, it was found that it was relatively the second biggest factor among those factors effecting reading skills success and this effect was in the positive direction. In this sense, permanent learning gains can be improved upon by realizing education practices towards the effective use of control strategies together with students.

The analysis of the findings related to the variable "enjoyment of reading" indicated that it positively efected reading skills success. Accordingly, stimulants that students would enjoy can be used effectively within the educational process.

When the findings regarding "diversity of reading material" were examined, it was found that students performed different types of reading activities in all the countries where the PISA project was carried out, except for Turkey and Kazakhstan, and they were more successful than students performing more limited reading activities. In this sense, Turkey differs from other countries on the basis of the findings relating to "diversity of reading material". "Diversity of reading material" negatively effected reading skills success. Accordingly, planning activities where students would enjoy reading and performing activities, where they would gain reading habits could be important to yield more positive results for students in Turkey.

The variable "reading for school" which had the largest value among the seven factors effecting reading skills success in terms of the variance ratio it explained, had a negative impact upon reading skills success. In this sense, selecting reading activities performed for school from the subjects that students might have an interest in and enjoy could be preferred because it could yield more positive results.

Although their effects are inconsiderable, diversity of on-line reading activities positively effected reading skills success. Accordingly, on-line activities could be carried out by ensuring the supervision of the students and providing correct guidance to them as a family, school and individual.

\section{REFERENCES}

Albayrak A. S. (2006). Uygulamalı Çok Değişkenli İstatistik Teknikleri. Ankara 2006.

Anderson J. C. \& Gerbing D. W. (1988). "Structural Equation Modeling in Practice: A Review and Recommended Two-Step Approach". Psychological Bulletin 103 (1988) 411-423.

Applebee A. N., Langer J. A. \& Mullis I. V. S. (1988). Who Reads Best? Factors Related to Reading Achievement in Grades 3, 7, and 11. New Jersey 1988.

Assor, A., Kaplan H. \& Roth G. (2002). "Choice is Good, but Relevance is Excellent: AutonomyEnhancing and Suppressing Teacher Behaviours in Predicting Student's Engagement in School Work". British Journal of Educational Psychology 72 (2002) 261-278.

Baker L. \& Wigfield A. (1999). "Dimensions of Children's Motivation for Reading and Their Relations to Reading Activity and Reading Achievement". Reading Research Quarterly 348 (1999) 452-497.

Büyüköztürk Ş. (2002). "Faktör Analizi: Temel Kavramlar ve Ölçek Geliştirmede Kullanımı". Kuram ve Uygulamada Eğitim Yönetimi Dergisi 32 (2002) 470-483.

Büyüköztürk Ş. (2012). Sosyal Bilimler İçin Veri Analizi El Kitabı, İstatistik, Araştırma Deseni SPSS Uygulamalart ve Yorumu. Ankara 2012.

Byrne B. M. (1989). A primer of LJSREL: Basic Applications and Programming for Confirmatory Factor Analytic Models. New York 1989.

Chiu M. M. \& McBride-Chang C. (2006). "Gender, Context, and Reading: A Comparison of Students in 
41 countries". Scientific Studies of Reading 10 (2006) 331-362.

Cipielewski J. \& Stanovich K. E. (1992). "Predicting Growth in Reading Ability from Children's Exposure to Print”. Journal of Experimental Child Psychology 54 (1992) 74-89.

Cunningham A. E. \& Stanovich K. E. (1998). "Early Reading Acquisition and its Relation to Reading Experience and Ability 10 Years Later". Developmental Psychology 33/6 (1998) 934-945.

Çokluk Ö., Şekercioğlu G. \& Büyüköztürk Ş. (2010). Sosyal Bilimler İçin Çok Değişkenli İstatistik: SPSS ve LISREL Uygulamalart. Ankara 2010.

Durik A. M., Vida M. \& Eccles J. S. (2006). "Task Values and Ability Beliefs as Predictors of High School Literacy Choices: A Developmental Analysis". Journal of Educational Psychology 98/2 (2006) 382-393.

Gottfried A. E. (1990). “Academic Intrinsic Motivation in Young Elementary School Children”. Journal of Educational Psychology 82/3 (1990) 525-538.

Greene B. A., Miller R. B., Crowson M., Duke B. L. \& Akey K. L. (2004). "Predicting High School Students' Cognitive Engagement and Achievement: Contributions of Classroom Perceptions and Motivation". Contemporary Educational Psychology 29 (2004) 462-482.

Guthrie J. T. \& Coddington C. S. (2009). "Reading Motivation”. Eds. K. R. Wentzel and A. Wigfield, Handbook of Motivation at School. New York.

Guthrie J. T. \& Wigfield A. (2000). "Engagement and Motivation in Reading". Eds. M. L. Kamil and P. B. Mosenthal. Handbook of Reading Research (2000) 403-417. New Jersey.

Hair J. F., Anderson R. E., Tahtam R. L. \& Black W. C. (1998). Multivariate Data Analysis Fifth Edition. New Jersey 1998.

Hauser R. M., Edley Jr, C. F., Koening J. A. \& Elliott S. W. (2005). Measuring Literacy: Performance Levels for Adults. Washington 2005.

Holloway J. H. (1999). "Improving the Reading Skills of Adolescents". Educational Leadership 57/2 (1999) 80-82.

Karasakaloğlu N. (2010). "Prospective Teachers' usage of Reading Strategies”. European Journal of Social Sciences 16/2 (2010) 229-238.

Kline P. (1994). An Easy Guide to Factor Analysis. New York 1994.

Kline R. B. (1991). "Latent Variable Path Analysis in Clinical Research: A Beginner's Tour Guide”. Journal of Clinical Psychology 47 (1991) 471-484.

Köksal K. \& Ünal E. (2008). “Metinler Arası Okumanın Okuduğunu Anlamaya Etkisi”. Elektronik Sosyal Bilimler Dergisi 7/26 (2008) 154-169.

Mason J. (1980). "When Do Children Learn to Read: An Exploration of Four-Year Old Children's Letter and Word Reading Competencies". Reading Research Quarterly 2 (1980) 202-227.

MEB (2010). PISA 2009 Uluslararası Öğrenci Değerlendirme Programı Ulusal Ön Raporu. Ankara 2010.

Mills K. A. (2010). "A Review of the "Digital Turn" in the New Literacy Studies". Review of Educational Research 80/2 (2010) 246-271.

Morrow L. M. (1983). "Home and School Correlates of Early Interest in Literature". Journal of Educational Research 76 (1983) 221-230.

Nurmi J. E., Aunola K., Salmela-Aro K. \& Lindroos M. (2003). "The Role of Success Expectation and Task-Avoidance in Academic Performance and Satisfaction: Three Studies on Antecedents, Consequences and Correlates". Contemporary Educational Psychology 28 (2003) 59-91.

OECD (2010a). PISA 2009 Results: What Students Know and Can Do: Student Performance in Reading, Mathematics and Science, Vol, I. Paris 2010.

OECD (2010b). PISA 2009 Results: Learning to Learn: Student Engagement, Strategies and Practices Vol. III. Paris 2010.

Otis N., Grouzet Frederick M. E. \& Pelletier L. G. (2005). "Latent Motivational Change in an Academic Setting: A 3-Year Longitudinal Study”. Journal of Educational Psychology 97/2 (2005) 170-183.

Özdamar K. (2004). Paket Programlar ile İstatistiksel Veri Analizi, Çok Değişkenli İstatistikler, 2. Cilt. 
Eskişehir 2004.

Özdamar K. (2009). Paket Programlar ile İstatistiksel Veri Analizi, Çok Değişkenli İstatistikler, 1. Cilt. Eskişehir 2009.

Quinn B. \& Jadav A. D. (1987). “Causal Relationship between Attitude and Achievement for Elementary Grade Mathematics and Reading”. Journal of Educational Research 80 (1987) 366-372.

Roettger D., Szymczuk M. \& Millard J. (1979). "Validation of a Reading Attitude Scale for Elementary Students and an Investigation of the Relationship between Attitude and Achievement". The Journal of Educational Research 72/3 (1979) 138-143.

Rowell C. G. (1972-73). “An Investigation of Factors Related to Change in Attitude toward Reading”. Journal of Reading Behavior 5 (1972-73) 266-272.

Scarborough H. S., Dobrich W. \& Hager M. (1991). "Preschool Literacy Experience and Later Reading Achievement”. Journal of Learning Disabilities 24/8 (1991) 508-511.

Schermelleh-Engel K., Moosbrugger H. \& Müller H. (2003). "Evaluating the Fit of Structural Equation Models: Tests of Significance and Descriptive Goodness-of-Fit Measures". Methods of Psychological Research Online 8/2 (2003) 23-74.

Schiefele U. (1991). "Interest, Learning, and Motivation". Educational Psychologist 26/3-4 (1991) 299323.

Schiefele U. (2009). "Situational and Individual Interest". Ed. K. R. Wentzel and A. Wigfield. Handbook of Motivation at School (2009) 197-222. New York.

Schofield H. L. (1980). "Reading Attitude and Achievement, Teacher-Pupil Relationship". Journal of Educational Research 74 (1980) 111-119.

Smith M. C. (1996). “Differences in Adults' Reading Practices and Literacy Proficiencies". Reading Research Quarterly 31/2 (1996) 196-219.

Smith M. C., L. Mikulecky, M. W. Kibby \& Dreher M. J. (2000). "What will be the Demands of Literacy in the Workplace in the Next Millennium?". Reading Research Quarterly 35/3 (2000) 378-383.

Şencan H. (2005). Sosyal ve Davranışsal Ölçümlerde Güvenlik ve Geçerlik. Ankara 2005.

Şimşek Ö. F. (2007). Yapısal Eşitlik Modellemesine Giriş Temel Illkeler ve LISREL Uygulamaları. Ankara 2007.

Tabachnick G., B. \& Fidell S. L. (2001). Using Multivariate Statistics, Fourth Edition. Boston 2001.

Topuzkanamış E. \& Maltepe S. (2010). "Öğretmen Adaylarının Okuduğunu Anlama ve Okuma Stratejilerini Kullanma Düzeyleri”. Türklük Bilimi Araştırmaları 25 (2010) 605-677.

Unrau N. \& Schlackman J. (2006). "Motivation and Its Relation to Reading Achievement in An Urban Middle School”. Journal of Educational Research 100/2 (2006) 81-101.

Van Ours J. C. (2008). When Do Children Read Books? Education Economics, 16/4, 313-328.

Wang J. H. Y. \& Guthrie J. T. (2004). "Modeling The Effects of Intrinsic Motivation, Extrinsic Motivation, Amount of Reading, and Past Reading Achievement on Text Comprehension Between U.S. and Chinese Students". Reading Research Quarterly 39/2 (2004) 162-186.

Wigfield A. \& Guthrie J. T. (1997). "Relations of Children's Motivation for Reading to the Amount and Breadth of Their Reading”. Journal of Educational Psychology 89/3 (1997) 420-432.

Worthy J., Patterson E., Salas R., Prater S. \& Turner M. (2002). "More Than Just Reading: The Human Factor in Reaching Resistant Readers". Reading Research \& Instruction 41/2 (2002) 177-202.

Zimmerman B. J. \& Clearly T. J. (2009). "Motives to Self-Regulate Learning: A Social Cognitive Account”. Eds. K. R. Wentzel and A. Wigfield. Handbook of Motivation at School (2009) 247-264. New York.

Zimmerman B. J. \& Martinez-Pons M. (1986). "Development of a Structured Interview for Assessing Student Use of Self-Regulated Learning Strategies”. American Educational Research Journal 23/4 (1986) 614-628.

Zimmerman B. J. \& Martinez-Pons M. (1990). "Student Differences in Self-Regulated Learning: Relating Grade, Sex, and Giftedness to Self-Efficacy and Strategy Use”. Journal of Educational Psychology 82/1 (1990) 51-59. 